\title{
Prevalence of Vitamin B12 and Folate Deficiencies and Homocysteinemia in Elderly Population of Shiraz, Southern Iran
}

\author{
Kamran B Lankarani ${ }^{1}$, Payam Peymani ${ }^{1 \star}$, Sahar Zare ${ }^{2}$, Reza Tabrizi ${ }^{1}$, MH \\ Kazemi $^{3}$ and GR Omrani ${ }^{3}$ \\ ${ }^{1}$ Health Policy Research Center, ${ }^{2}$ Faculty of Dentistry, International Branch, ${ }^{3}$ Department of Internal Medicine \& Endocrine and \\ Metabolism Research Centre, Namazi Hospital, Shiraz University of Medical Sciences, Shiraz, Iran \\ *For correspondence: Email: Peymani.payam@gmail.com, peymanip@sums.ac.ir
}

\begin{abstract}
Purpose: To investigate the prevalence of cobalamin and folate deficiencies among the elderly in the general population of Shiraz in southern Iran.

Methods: This is a descriptive cross-sectional study including 340 individuals who are over 50 years old and were selected randomly from all the regions of Shiraz.

Results: The study group was made up of 132 (38.8\%) males and 208 (61.2\%) females. In this group $174(51.2 \%)$ were aged 50 - 59 years and $166(48.8 \%)$ were aged $\geq 60$ years. Cobalamin deficiency (< $200 \mathrm{pg} / \mathrm{mL}$ ) was present in 124 (36.2 \%) while $42(12.4 \%)$ had severe deficiency with levels < 100 $\mathrm{pg} / \mathrm{mL}$. Signs of metabolic deficiency at the cellular level were seen in $21(5.25 \%)$ of the samples. Serum folate deficiency $(<4 \mathrm{ng} / \mathrm{mL})$ was present in 134 (39.4\%) while 19 (5.6\%) persons had severe folate deficiency $(\leq 2-3 \mathrm{ng} / \mathrm{mL})$. Correlation analysis showed that serum cobalamin and homocysteine in the study samples were not significant $(p>0.05)$.

Conclusion: The prevalence of severe cobalamin deficiency with clinical significance is high in the elderly population of Shiraz, Iran.
\end{abstract}

Keywords: Vitamin B12 deficiency, Folate deficiency, Homocysteinemia, Elderly population

\begin{abstract}
Tropical Journal of Pharmaceutical Research is indexed by Science Citation Index (SciSearch), Scopus, International Pharmaceutical Abstract, Chemical Abstracts, Embase, Index Copernicus, EBSCO, African Index Medicus, JournalSeek, Journal Citation Reports/Science Edition, Directory of Open Access Journals (DOAJ), African Journal Online, Bioline International, Open-J-Gate and Pharmacy Abstracts
\end{abstract}

\section{INTRODUCTION}

Vitamin B12 (Cobalamin) is a water-soluble vitamin. Its main role in the body is to transfer methyl groups. Cobalamin is needed for two actions; one of them is conversion of methyl malonyl co-A to succinyl co-A and the other is conversion of homocysteine to methyonin [1]. Vitamin B12 deficiency occurs with atrophic gastritis, intestinal malabsorption, pancreatic insufficiency, decreased intake, consumption of some drugs, inborn errors, transcobalamin I deficiency and errors of cobalamin metabolism [1].

Elderly people are at increased risk of B12 deficiency, due to the risk of both reduced intake and decreased absorption [2-5]. In this context, serum B12 monitoring has been suggested for the elderly [6]. Vitamin B12 deficiency has no specific sign and symptom, but this disease can have indicators such as anemia, psychoneurologic symptoms, parasthesia, sensory loss and dementia [7-11]. Cobalamin 
deficiency may increase serum homocysteine [12].

High amount of homocysteine have been correlated with increased risk of cardiovascular disease especially in elderly [13]. Homocysteinemia may be caused by several nutritional deficiencies other than B12, including vitamin B6 and folate deficiencies [14]. Depending on the cutoff levels, previous studies have reported the prevalence of vitamin B12 deficiency to be between 10 to $43 \%$ [15-18]. When serum level $<200 \mathrm{pg} / \mathrm{mL}$ was used as cut off, $10-15 \%$ of old people had vitamin B12 deficiency [21].

There are limited data on serum folate, vitamin B12 and homocysteine levels in the Islamic Republic of Iran. In the population, the consumption of all types of vegetables is high but meat consumption is lower than in western countries. In a survey conducted on the low income population in South West region of Tehran, Iran, age-adjusted incidences of low serum cobalamin was $27.2 \%$ in females and $26.32 \%$ in males. Moreover, low serum folate level was $97.92 \%$ in females and $98.67 \%$ in males $[15,16]$.

Folate deficiency can cause macrocytic anemia (low red blood cell count), and low levels of white blood cells and platelets in severe cases but may also show neural features that are different from those of vitamin B12 deficiency. Most people get enough folate from food. Inadequate folate status is highly prevalent in the adult population, while vitamin B12 status in young adults is generally sufficient. Nevertheless, older people often show vitamin B12 deficiency, and hence cobalamin supplementation may play a major role in lowering homocysteine levels in this group $[6,22]$. The aim of the present study was to determine the prevalence of vitamin B12 and folate deficiencies, and their possible association with each other and with homocysteine levels in over 50 years old population.

\section{METHODS}

\section{Study population}

Shiraz is a large metropolitan city in southern Iran with a population of $1,460,665$, according to 2011 census. A weighted cluster random sampling technique was used to gather the samples from all the regions of Shiraz, based on the population of municipality data. Those aged $\geq$ 50 years, who were apparently healthy and not on any medication were invited to participate by some health members of staff that were referred to their houses. Those who agreed to participate were informed about the study and signed a consent form. They were referred to Namazi hospital after $12 \mathrm{~h}$ of fasting in the morning where a physician took their complete medical history and performed physical examination. A five milliter blood sample was collected from those who were found to be healthy. The serum was separated within one hour after sampling and was refrigerated in temperature $-20{ }^{\circ} \mathrm{C}$ (freezing).

\section{Laboratory methods}

All the samples were tested at the same time (in one day) for Cobalamin, homocysteine and Folate. Cobalamin and Folate were measured by Radioisotope dilution using Simult RAC-SNB kit (ICN Co, USA); homocysteine was measured by ELISA (DRG Co, USA). Those samples that were used for calibration were consistent with their companies (IDEAL TASHKHIS Co, Iran).

\section{Determination of cobalamin, folate and homocysteine status}

Cutoff levels of $<200 \mathrm{pg} / \mathrm{mL}$ for cobalamin deficiency and $<100 \mathrm{pg} / \mathrm{mL}$ for severe deficiencies were used. Folate deficiency that was defined as serum levels below $4 \mathrm{ng} / \mathrm{mL}$ and $2.3 \mathrm{ng} / \mathrm{mL}$ was considered severe deficiency. Homocysteine deficiency was defined as serum levels > $15 \mu \mathrm{mol} / \mathrm{l}$ and < $21.3 \mu \mathrm{mol} / \mathrm{l}$ was considered severe deficiency. Homocysteine serum level of $>21.3 \mu \mathrm{mol} / \mathrm{L}$ was considered abnormal in this study.

\section{Data analysis}

The results are presented as mean \pm SD and the percentage based on sex and age group were used to express the prevalence of variable blood factors. In the statistical analysis of the relationship between variables, T-test and Pearson correlation were used. The data were analyzed using SPSS 18 software, and $p<0.05$ was considered significant.

\section{RESULTS}

Three hundred and forty people aged $\geq 50$ years including 132 males (38.8\%) and 208 females $(61.2 \%)$ participated in this study. In this group 174 (51.2 \%) were aged between 50-59 years and $166(48.8 \%)$ were aged 60 years or above (Table 1).

Trop J Pharm Res, October 2015; 14(10): 1908 
Table 1: Demographic characteristics of samples

\begin{tabular}{|c|c|c|c|c|}
\hline \multirow[t]{2}{*}{ Age group } & \multirow[t]{2}{*}{ Number (\%) } & \multicolumn{2}{|c|}{ Gender } & \multirow[t]{2}{*}{ Total } \\
\hline & & Male & Female & \\
\hline & Number & 57 & 117 & 174 \\
\hline \multirow[t]{2}{*}{$50-59$ years } & $\%$ in group & $32.8 \%$ & $67.2 \%$ & $100 \%$ \\
\hline & $\%$ in gender & $43.2 \%$ & $56.3 \%$ & $51.2 \%$ \\
\hline \multirow[t]{4}{*}{$>60$ years } & Number & 75 & 91 & 166 \\
\hline & $\%$ in group & $45.2 \%$ & $54.8 \%$ & $100 \%$ \\
\hline & $\%$ in gender & $56.8 \%$ & $43.8 \%$ & $48.8 \%$ \\
\hline & Number & 132 & 208 & 340 \\
\hline \multirow[t]{2}{*}{ Total } & $\%$ in group & $38.8 \%$ & $61.2 \%$ & $100 \%$ \\
\hline & $\%$ in gender & $100 \%$ & $100 \%$ & $100 \%$ \\
\hline
\end{tabular}

\section{Prevalence of cobalamin deficiency}

In this study, the mean amount of cobalamin serum level in all samples was $386.6 \pm 46 \mathrm{pg} / \mathrm{mL}$, with a range from 0 to $1886 \mathrm{pg} / \mathrm{mL}$. Figure 1 demonstrates the distribution of samples on the basis of serum cobalamin. In most of the samples cobalamin serum level was below 300 $\mathrm{pg} / \mathrm{mL}$ (in 189 samples which equals more than
$55 \%)$, and in $205(60.2 \%)$ of the samples cobalamin serum level was below the normal mean $(350 \mathrm{pg} / \mathrm{mL})$.

124 people $(36.4 \%)$ had their cobalamin level < $200 \mathrm{pg} / \mathrm{ml}$, and $42(12.3 \%)$ had severe cobalamin deficiency with cobalamin level $<100 \mathrm{pg} / \mathrm{mL}$. Of those with severe deficiency, $29(69.04 \%)$ were females and 13 (30.96) of males (Figure 2).

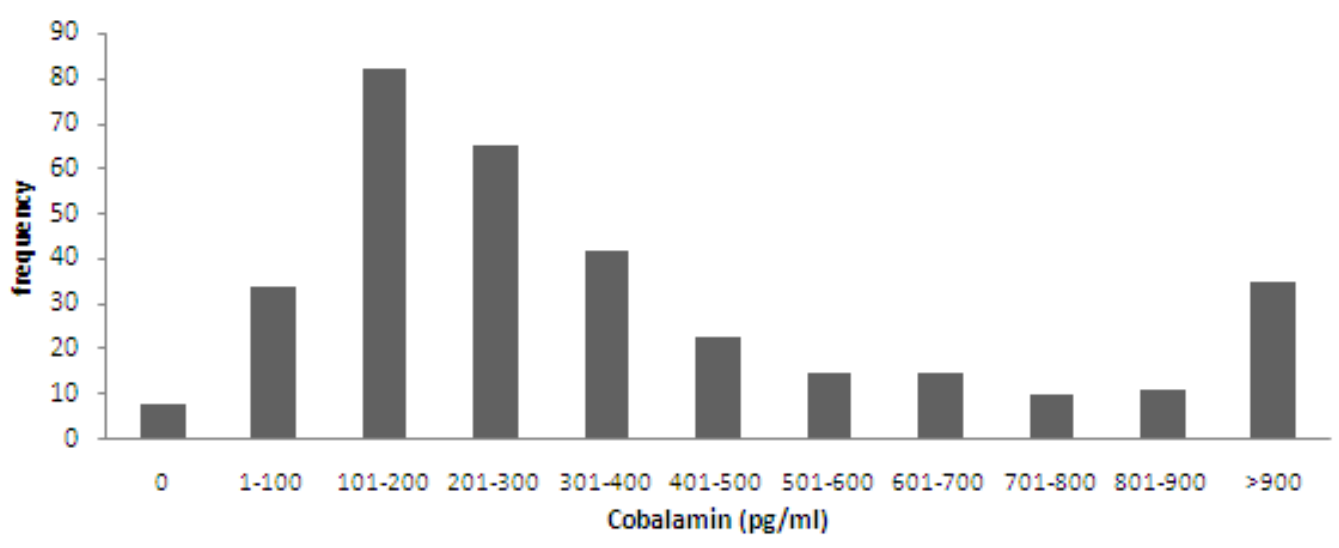

Figure 1: Frequency distribution of the samples based on Cobalamin $(\mathrm{pg} / \mathrm{mL})$ (Key: Acceptable, $>200 \mathrm{pg} / \mathrm{mL}$; deficiency: $100-200 \mathrm{pg} / \mathrm{mL}$; severe deficiency $<100 \mathrm{ng} / \mathrm{mL}$ )

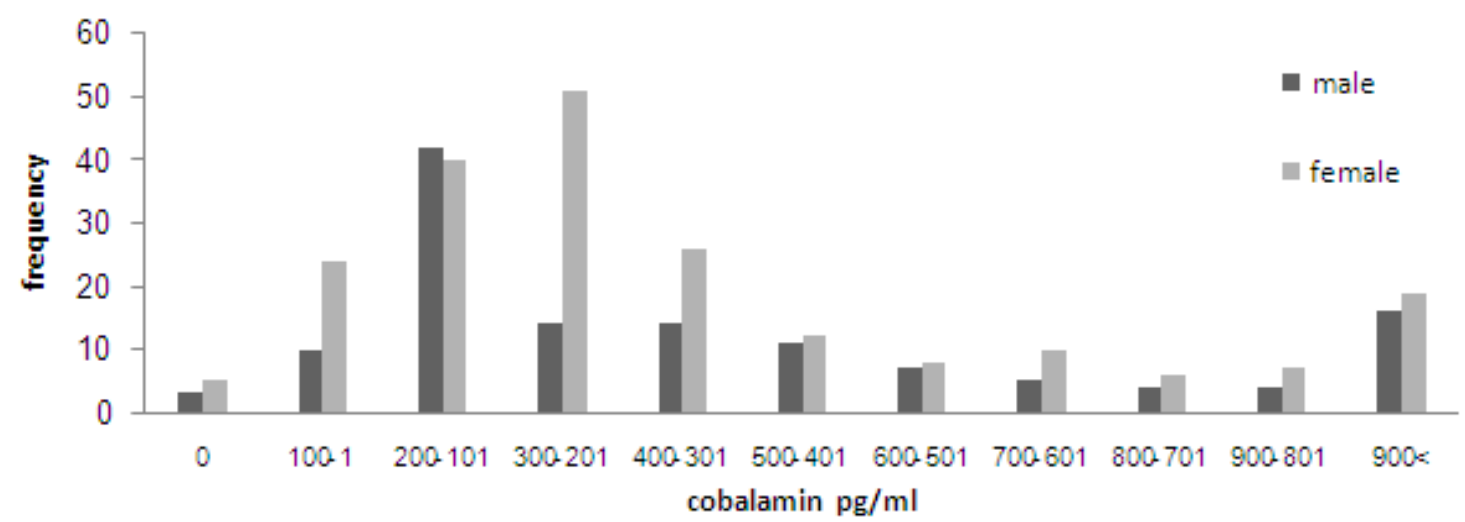

Figure 2: Frequency distribution of the samples based on cobalamin by gender $(\mathrm{pg} / \mathrm{ml})$ 
In the 50 - 59 years age group, cobalamin serum level below $200 \mathrm{pg} / \mathrm{mL}$ was seen in 67 persons and severe cobalamin deficiency was present in 23 persons. The figures for those aged $\geq 60$ years were 57 and 19 persons.

The number of people whose cobalamin levels were less than the normal mean \pm SD (300 $\mathrm{pg} / \mathrm{mL})$ was $70(20.6 \%)$. Of these, $35(20.1 \%)$ persons were aged $50-59$ years and 35 (21.1 $\%$ ) were $>60$ years old (Figure 2).

\section{Prevalence of folate deficiency and homocysteine}

The mean serum level of folate was $5.8 \pm$ $3.02 \mathrm{ng} / \mathrm{mL}$ (mean $\pm \mathrm{SD}$ ), ranging from 0 to 18.1 $\mathrm{ng} / \mathrm{mL}$. Table 4 shows the findings related to serum level of folate according to age and gender groups. The mean serum level of folate in people aged 50 - 59 years was $5.4 \mathrm{ng} / \mathrm{mL}$, with
$5.29 \mathrm{ng} / \mathrm{mL}$ in males and $6.2 \mathrm{ng} / \mathrm{mL}$ in females of this age group.

The value in those $\geq 60$ years old was 5.83 $\mathrm{ng} / \mathrm{mL}$, with $5.95 \mathrm{ng} / \mathrm{mL}$ in males and $5.74 \mathrm{ng} / \mathrm{mL}$ in females.

According to the statistical comparison, there were no significant differences between this numbers $(p>0.05)$.

Based on the definition of serum folate deficiency $19(5.6 \%)$ persons had severe folate deficiency and the folate serum level of 134 (39.4\%) persons were below $4 \mathrm{ng} / \mathrm{mL}$.

\section{Homocysteinemia}

The mean serum level of homocysteine was 15.2 $\mu \mathrm{mol} / \mathrm{L}$ with a range from $4.5 \mu \mathrm{mol} / \mathrm{L}$ up to 50.3 $\mu \mathrm{mol} / \mathrm{L}$ (Table 4).

Table 4: Indicators of homocysteine, folate, and homocysteine serum level variables, by sex and age group

\begin{tabular}{|c|c|c|c|c|c|c|c|}
\hline Gender & $\begin{array}{c}\text { Age groups } \\
\text { (number of } \\
\text { samples) }\end{array}$ & Variable & Minimum & Maximum & Mean & $\begin{array}{l}\text { Standard } \\
\text { Error }\end{array}$ & $\begin{array}{l}\text { Standard } \\
\text { deviation }\end{array}$ \\
\hline \multirow[t]{4}{*}{ Male } & $\begin{array}{l}50-59 \text { years old } \\
(57)\end{array}$ & $\begin{array}{l}\text { Folate } \\
\text { serum level } \\
(\mathrm{ng} / \mathrm{ml})\end{array}$ & 1.8 & 12.2 & 5.29 & 0.385 & 9.2 \\
\hline & & $\begin{array}{l}\text { Homocystei } \\
\text { ne serum } \\
\text { level } \\
(\mu \mathrm{mol} / \mathrm{l})\end{array}$ & 6.9 & 50.3 & 18.3 & 1.2 & 9.06 \\
\hline & $\begin{array}{l}>60 \text { years } \\
\text { Old } \\
(75)\end{array}$ & $\begin{array}{l}\text { Folate } \\
\text { serum level } \\
(\mathrm{ng} / \mathrm{ml})\end{array}$ & 0 & 16 & 5.59 & 0.361 & 3.1 \\
\hline & & $\begin{array}{l}\text { Homocystei } \\
\text { ne serum } \\
\text { level } \\
(\mu \mathrm{mol} / \mathrm{l})\end{array}$ & 4.5 & 47.2 & 15.47 & 0.78 & 6.83 \\
\hline \multirow[t]{4}{*}{ Female } & $\begin{array}{l}50-59 \text { years old } \\
(117)\end{array}$ & $\begin{array}{l}\text { Folate } \\
\text { serum level } \\
(\mathrm{ng} / \mathrm{ml})\end{array}$ & 1.9 & 18.1 & 6.2 & 0.314 & 4.3 \\
\hline & & $\begin{array}{l}\text { Homocystei } \\
\text { ne serum } \\
\text { level } \\
(\mu \mathrm{mol} / \mathrm{l})\end{array}$ & 5.1 & 32.5 & 14.93 & 0.47 & 5.10 \\
\hline & $\begin{array}{l}>60 \text { years } \\
\text { Old } \\
(91)\end{array}$ & $\begin{array}{l}\text { Folate } \\
\text { serum level } \\
(\mathrm{ng} / \mathrm{ml})\end{array}$ & 1.8 & 16.2 & 5.74 & 0.374 & 3.03 \\
\hline & & $\begin{array}{l}\text { Homocystei } \\
\text { ne serum } \\
\text { level } \\
(\mu \mathrm{mol} / \mathrm{l})\end{array}$ & 4.6 & 30.2 & 13.4 & 0.45 & 4.28 \\
\hline
\end{tabular}




\section{DISCUSSION}

The findings shows that the prevalence of cobalamin serum level below $200 \mathrm{pg} / \mathrm{mL}$ was $36.47 \%$, while severe cobalamin deficiency with clinical significant was $12.35 \%$. This results in different countries with regard to race and ethnic differences are varies. It had been reported from 4 to $55 \%$. [23,24]. However, most studies have reported the prevalence to be between 10 and 30 $\%$ depending on the criteria used [25].

A study on the elderly population of northeastern Iran showed that the prevalence of cobalamin deficiency with low levels $(<122 \mathrm{pg} / \mathrm{mL})$ was $22.7 \%$ and with borderline levels (122 - 330 $\mathrm{pg} / \mathrm{mL}$ ) was $51.8 \%$ [15]. But, what is striking in this study is the high prevalence of cobalamin deficiency in the population under study. Also, the prevalence of cobalamin deficiency according to the cobalamin serum level below $200 \mathrm{ng} / \mathrm{mL}$ was $33.1 \%$ in females and $41.6 \%$ in males, of which our results were similar to those of the other studies, the prevalence of cobalamin deficiency in males was more than females [23]. But severe vitamin B12 deficiency in females was $13.9 \%$ and was $9.8 \%$ in males, therefore, the percentage of severe deficiency is higher in females. The present study was similar to another study, where the results showed that, the prevalence of cobalamin deficiency weren't based on age groups but rather were gender statistically significant [23]

In this study $5.25 \%$ of the study samples had problems in cellular metabolism, and this number is similar to Faringham's study results [23]. Taking into account that clinical signs are very different in cases with cobalamin deficiency, in some cases where the cobalamin serum levels were very low, there were no sign of deficiency [26], and sometimes in some people with cobalamin serum levels that are a little below normal, we can see neurological signs. Therefore, serum level itself cannot determine the severity of the disease [24,25,27-30]. However, serum levels $<100 \mathrm{pg} / \mathrm{mL}$ is clinically significant.

The mean level for serum cobalamin was $383.6 \pm$ $46 \mathrm{pg} / \mathrm{mL}$ which was higher than the normal mean in other studies [23]. There is a possibility that it was due to the high percentage of people having higher serum cobalamin $900 \mathrm{pg} / \mathrm{mL}$ (about $10.2 \%$ of the sample). There are a few published studies that have reported serum folate in Iranians. Based on the results, $5.65 \%$ of the people had serum folate deficiency $(<2.3$ $\mathrm{ng} / \mathrm{mL}$ ), and severe folate deficiency (below 4 $\mathrm{ng} / \mathrm{mL}$ ) was in $39.4 \%$ of them. This it is almost similar to the results of a study that was conducted in Tehran on 1214 healthy persons [15].

The mean of homocysteine serum level in our study was $15.1 \mu \mathrm{mol} / \mathrm{L} \pm 3.6$, which is higher than other populations $(5-15 \mu \mathrm{mol} / \mathrm{L})$. A possible reason could be that the samples in our study were for those older $>50$ years, while in other studies they were $<55$ years or for all ages $[31,32]$. It may be that the mean serum level of homocysteine in our society for some other reasons is really higher than others [23,32].

On the other hand, the statistical comparison showed there were no significant correlation between cobalamin serum level and homocysteine serum level in our samples, and this result differs from the study done by Vakili et al [6]. It may be that this lack of significant correlation relates to the difference in the levels of B6 and folate level in both this and the other studies [6]. Also, correlation analysis showed that generally, homocysteine and folate serum level were indirectly correlated, and this funding was similar other studies $[6,23]$. An important problem encountered when comparing the prevalence of the levels of organic compounds based on studies is the variation of cut-offs point used to define shortage. In order to make results comparable, criteria and standards should be defined. Hence, the re-definition of criteria and standards can be tackled in future studies.

\section{CONCLUSION}

The results of this study show that the prevalence of cobalamin deficiency in the study population is high. Steps and some strategies, such as administering folic acid and vitamin B12 to elderly people, will help to reduce the deficiencies observed.

\section{ACKNOWLEDGEMENT}

This work was supported by grants from the Vice-Chancellor of Research, Shiraz University of Medical Sciences. This study forms part of the $\mathrm{PhD}$ thesis of Dr Payam Peymani (Thesis no. 926907).

\section{REFERENCES}

1. Metabolic Aspects of Folic Acid and Cobalamin. In: Babior BM, Ed. Williams Textbook of Hematology, 6th edn, New York: McGraw-Hill, 2001; pp 305-308.

Trop J Pharm Res, October 2015; 14(10): 1911 
2. Baik HW, Russell RM. Vitamin B12 deficiency in the elderly. Annu Rev Nutr 1999; 19: 357-377.

3. Saltzman JR, Russell RM. The Aging Gut Nutritional Issues. Gastroenterol Clin North Am 1998; 27: 309324.

4. Selhub J, Bagley LC, Miller J, Rosenberg IH. B vitamins, homocysteine, and neurocognitive function in the elderly. Am J Clin Nutr 2000; 71: 614- 620.

5. Wolters M, Strohle A, Hahn A. Cobalamin: a critical vitamin in the elderly. Prev Med 2004; 39: 1256-1266.

6. Vakili $M$, Forooghan $M$, Ghaleh-Bandi MF, Nojomi $M$, Khodabandeloo N. A Survey on Serum Levels of B12, Folate and Homocysteine in Healthy Elderly Tehranis. Iran J Med Sci 2009; 16: 189-201.

7. Gulley ML, Bentley SA, Ross DW. Neutrophil meloperoxidase measurement uncovers masked megaloblastic anemia. blood 1990; 76: 1004-1007.

8. Marshal RA, Jandl HH. Responses to "physiologic" dosesnof folic acid in the megaloblastic anemias. Arch Intern Med 1960; 105: 352-360.

9. Victor $M$, Lear $A A$. Substance combined degeneration of the spainal cord:current concepts of the disease: value of serum vitamin B12 determinations in clarify some of the common clinical problems. AM J Med 1956; 20: 896-911.

10. Fraser TN. Cerbral manifestations of addisonian pernicious anemia. lancet 1960; 2: 458-459.

11. Stojsavljevic N, levine Z, Drulovic J, Dragutinovic G. A 44-month clinical-brian MRI follow-up in a patient with B12 deficiency. Neurology 1996; 49: 878-881.

12. Stabler SP, Lindenbaum J, Allen $R H$. The use of homocysteine and other metabolites in the specific diagnosis of vitamin B12 deficiency. J Nutr 1996; 126. 66-72.

13. Kazemi MS, Eshraghian K, Omrani G, Lankarani KB, Hosseini E. Homocysteine level and coronary artery disease. Angiology 2006; 57:9-14.

14. Johnson MA. If High Folic Acid Aggravates Vitamin B12 Deficiency What Should Be Done About It? Nutr Rev 2007; 65: 451-458.

15. Manavifar L, Jamali J, Talebidoluee $M$, Shirdel $A$, Nejatshokohi A, Fateminayyeri M. Homocysteine, Cobalamin and Folate Status and their Relations to Neurocognitive and Psychological Markers in Elderly in Northeasten of Iran. Iran J Basic Med Sci 2013; 16: 772-780.

16. Shams M, Omrani GR. Serum folate and vitamin $B 12$ status in healthy Iranian adults. East Mediterr Health J. 2009; 15: 1285-1292.

17. Wolters $M$, Hermann $S$, Hahn A. B vitamins, homocysteine, and methylmalonic acid in elderly German women. Am J Clin Nutr 2003; 78:765-772.

18. Bjorkegren K, Svardsudd K. Elevated serum levels of methylmalonic acid and homocysteine in derly people. A population-based intervention study. J Int Med 1999; 246: 317-324.

19. Bjorkegren K, Svardsudd K. Serum cobalamin, folate, methylmalonic acid and total homocysteine as vitamin B12 and folate tissue deficiency markersamongst elderly Swedes-A population-based study. J Intern Med 2001; 249: 423-432.

20. Herrmann W, Schorr H, Bodis M, Knapp JP, Müller A, Stein G, Geisel J. Role of homocysteine, cystathionine and methylmalonic acid measurement for diagnosis of vitamin efficiency in high-aged subjects. Eur J Clin Invest 2000; 30: 1083-1089.

21. Klee G. Cobalamin and folate evaluation: measurement of methylmalonic acid and homocysteine vs vitamin B12 and folate. Clin Chem 2000; 46:1277-1283.

22. Stabler SP, Lindenbaum J, Allen RH. Vitamin B12 deficiency in the elderly: current dilemmas. Am J Clin Nutr 1997; 66:741- 749.

23. Stabler SP. Vitamin B12 deficiency in older people:improving diagnosis and preventing disability. J Am Geriatr Soc 1998; 46:1317- 1319.

24. Lindenbaum J. Prevalence of cobalamin deficiency in the framingham elderly population. Am J Clin Nutr 1994; 60: 2-11.

25. Lindsay $H$, casterline $j$. vitamin B12 deficiency in elderly individuals: diagnosis and requirements. Am J Clin Nutr 1994; 60: 4-12.

26. Kasper DL, Braunwald E, Fauci A, Hauser S, Longo D, Jameson, JL, Harrison's principles of internal medicine. New York: McGraw-Hill, 15th edn, 2001; $p$ 674.

27. Cuskelly GJ, Mooney KM, Young IS. Folate and vitamin B12: friendly or enemy nutrients for the elderly. Proc Nutr Soc 2007; 66: 548-558.

28. Herbert V. Minimal daily adult folate requirement. Arch Intern Med 1962;110:649-652.

29. Heyssel R, Bozan R, Darby W, Bell M. Vitamin B12 Turnover in Man The Assimulation of Vitamin B12 from Natural Foodstuff by Man and Estimates of Minimal Daily Dietary Requirements. Am J Clin Nutr 1966; 18: 176-184.

30. Schwarz RH, johnston RB. Folic acid supplementation when and how. Obstet Gynecol 1996; 88: 886-887.

31. Stites TE, Bailey $L B$, Scott KC, Toth JP, Fisher WP, Gregory J. Kinetic modeling of folate metabolism through use of chronic administration of deuteriumlabeled folic acid in men. Am J Clin Nutr 1997; 65: 53-60.

32. Carmel R, Green R, Jacobsen DW, Rasmussen $K$, Florea $M$, Azen C. serum cobalamin, homocysteine, and methyl malanic acid concentrations in a multiethnic elderly population: ethnic and sex differences in cobalamin and methabolic abnormalities. Am J Clin Nutr 1999; 70: 904-910. 